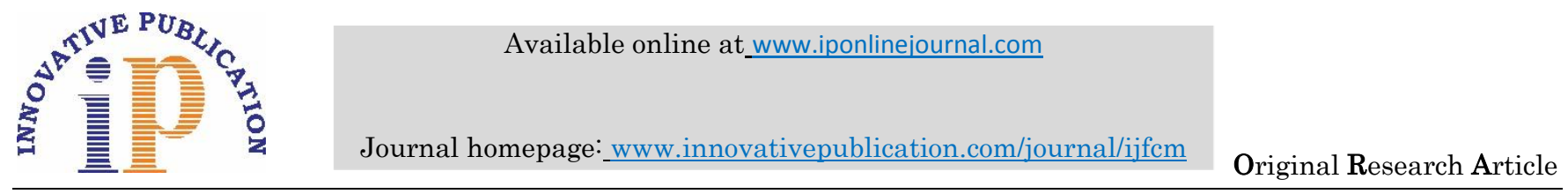

\title{
Awareness of HIV among health care workers in a tertiary care hospital of Jammu
}

\author{
Devika Rakesh $^{1 *}$, Ruchita Mahajan ${ }^{2}$, Sarika Ghai $^{3}$ \\ ${ }^{\mathbf{1}}$ Post Graduate Resident, ${ }^{\mathbf{2}}$ Medical Officer, ${ }^{\mathbf{3}}$ Assistant Professor, ${ }^{\mathbf{1}}$ Dept. of General Surgery, ${ }^{\mathbf{2 , 3}}$ Dept. of Microbiology, ${ }^{\mathbf{1 , 3}}$ Acharya Shri \\ Chander College of Medical Sciences and Hospital, Jammu, ${ }^{2}$ Govt. Medical College, Jammu, Jammu and Kashmir, India
}

\begin{abstract}
HIV/AIDS has emerged as the single most formidable challenge to public health and Health Care professionals. Apart from doctors and nurses, laboratory technicians and nursing orderlies are an important component of the health care delivery system and form a potential risk group for HIV/AIDS spread due to frequent and prolonged contact. In this group an adequate knowledge of the different aspects of the disease are of great importance, hence a cross-sectional study was carried out in a tertiary care hospital to assess the level of awareness of HIV/AIDS in health care workers. A pretested questionnaire was used as an investigating tool and distributed among the various respondents. The awareness regarding the infectious nature of the virus and methods of transmission was adequate though information regarding vertical transmission was a grey area in the respondents. Regarding the prevention of transmission of HIV in terms of practicing universal precautions was found to be in order of $88 \%, 84 \%, 84 \%$ and $74 \%$ among technicians, doctors, nurses and class IV workers. Availability of diagnostic tests for HIV infection was known mainly to doctors $(92 \%)$ and less than $60 \%$ of other workers. Knowledge of respondents about the benefits of PEP (post exposure prophylaxis) and ART (anti retro viral therapy) was not satisfactory. Thus, sensitizing the hospital staff to the various aspects of disease through an active health education programme in the form of CME's, posters, group discussion is required for effective control of the disease.
\end{abstract}

Keywords: HIV Awareness, Mode of transmission, Prevention, Risk Factors, Treatment.

\section{Introduction}

HIV/AIDS has emerged as the single most formidable challenge to public health, human rights, and development in the new millennium. ${ }^{1}$ The alarming rise of sexually transmitted diseases has put India in the top position in AIDS scenario in the Asian continent. ${ }^{2}$ India is one of the largest and most populated countries in the world, with over one billion inhabitants. In 2007, UNAIDS and the WHO issued HIV estimates for India; HIV had decreased from 5.7 million (3.4-9.4 million) people in 2005 to 2.5 million (2.03.1 million) people in 2006., $\mathrm{HIV}$ prevention efforts should concentrate on high-risk groups such as commercial sex workers and their clients, migrant laborers and truck drivers, medical professionals, and injection-drug users. ${ }^{5}$

The accidental transmission of HIV infection to health care workers during occupational exposure, are the real threats today. ${ }^{6}$ Many such cases have been documented by $\mathrm{NACO}$ and various other researchers.

Amongst the health care professionals, apart from doctors and nurses, laboratory technicians and nursing orderly are an important component of the health care delivery system. Since they are the one who are responsible for the constant care of in-patients and thus, they come in close contact with blood and other body fluids of patients. Due to frequent and prolonged contact, they are being identified as a potential risk group for the HIV/AIDS spread. To reduce the transmission, adequate knowledge about the disease and practice of safety measures are of great importance. Generating awareness regarding
HIV/AIDS in this group is crucial for AIDS management and the prevention of HIV spread.

Various trainings are conducted by the institutions to update the health care workers regarding their knowledge on AIDS. Data regarding the baseline knowledge of HIV/AIDS amongst HCWs and impact of these training programmes are required to modify the contents of the programme further. Keeping these two objectives in view, a crosssectional study was carried out to assess the awareness of Health Care Workers about HIV/AIDS and to identify the areas of confusion that might serve as an important aspect of educational intervention

\section{Materials and Methods}

The present study was undertaken by the Department of Surgery, ASCOMS in collaboration with the Department of Microbiology. The study was conducted over a period of 3 months from $1^{\text {st }}$ August 2017 to $31^{\text {st }}$ October 2017 to check the awareness of HIV/AIDS in health care associated individuals in a tertiary care hospital. Health care associated workers included four groups - doctors, nurses, technicians and class 4 employees. The investigating tool used was a prepared, pretested questionnaire. A Questionnaire having 25 set of questions was distributed among the various respondents of the four groups. Care was taken to minimize consultation among the respondents. Different factors related to HIV/AIDS and information was gathered. The subjects were assessed for knowledge of various aspects of HIV/AIDS, associated risk factors, mode of spread,

\footnotetext{
*Corresponding Author: Devika Rakesh, Dept. of General Surgery, Acharya Shri Chander College of Medical Sciences and Hospital, Jammu, Jammu \& Kashmir, India

Email: mahajan.devika@gmail.com

http://doi.org/10.18231/J.IJFCM.2019.030
} 
prevention and treatment. The questionnaire was collected from them and was analyzed for the answers given by each individual.
The study was conducted on 200 respondents which included 50 doctors, 50 nurses, 50 technicians and 50 nursing orderly staff of ASCOMS.

\section{Results}

Table 1: Distribution of respondents based on awareness about causative agent for AIDS

\begin{tabular}{|c|c|c|c|c|c|}
\hline Question & & $\begin{array}{c}\text { Agent } \\
\text { (Organism) }\end{array}$ & $\begin{array}{c}\text { Difference between } \\
\text { HIV \& AIDS }\end{array}$ & $\begin{array}{c}\text { Incubation } \\
\text { Period }\end{array}$ & $\begin{array}{c}\text { Affected system } \\
\text { in Host }\end{array}$ \\
\hline S. No. & Health workers & $\begin{array}{c}\text { Correct answers } \\
\text { given by } \\
\text { No. }(\%)\end{array}$ & $\begin{array}{c}\text { Correct answers given } \\
\text { by } \\
\text { No. }(\%)\end{array}$ & $\begin{array}{c}\text { Correct answers } \\
\text { given by } \\
\text { No. }(\%)\end{array}$ & $\begin{array}{c}\text { Correct answers } \\
\text { given by } \\
\text { No. }(\%)\end{array}$ \\
\hline 1. & & $50(100.00)$ & $49(98.00)$ & $20(40.00)$ & $50(100.00)$ \\
\hline 2. & Doctors & $47(94.00)$ & $44(88.00)$ & $29(58.00)$ & $42(84.00)$ \\
\hline 3. & Technicians & $50(100.00)$ & $44(88.00)$ & $7(14.00)$ & $45(90.00)$ \\
\hline 4. & Nurses & $46(92.00)$ & $22(44.00)$ & $19(38.00)$ & $39(78.00)$ \\
\hline Total & Class iv & $193(96.50)$ & $159(79.50)$ & $75(37.50)$ & $176(88.00)$ \\
\hline P value & & $\mathrm{p} 0.056$ & $\mathrm{p} 0.000000$ & 0.000111 & 0.005853 \\
\hline
\end{tabular}

Out of all the 200 respondents, 96.5\% gave correct responses about the infectious nature of AIDS. Out of them, all (100\%) of doctors and nurses were aware that AIDS is an infectious disease, followed by technicians (94\%) and class IV employees (92\%). $98 \%$ of the doctors followed by $88 \%$ each of nurses and technicians knew about the difference between HIV and AIDS. Only $44 \%$ of the class IV employees knew the difference. This difference was statistically highly significant (p 0.000000). Awareness of respondents about the system mainly affected by HIV was $100 \%, 90 \%, 84 \%$ and $78 \%$ doctors, nurses, technicians and class IV employees respectively and it was statistically significant $(0.005853)$

Table 2: Distribution of respondents based on awareness about Transmission of HIV

\begin{tabular}{|c|c|c|c|c|c|c|c|}
\hline & & $\begin{array}{c}\text { Infectivity of } \\
\text { asymptomatic } \\
\text { PLHIV }\end{array}$ & $\begin{array}{c}\text { HIV } \\
\text { transmission } \\
\text { potential of } \\
\text { Razor/ blades }\end{array}$ & $\begin{array}{c}\text { Body } \\
\text { secretions } \\
\text { containing } \\
\text { HIV }\end{array}$ & $\begin{array}{c}\text { Routes of } \\
\text { transmission }\end{array}$ & $\begin{array}{c}\text { Risk of } \\
\text { transmission } \\
\text { in MTCT }\end{array}$ & $\begin{array}{c}\text { Transmission } \\
\text { of HIV in } \\
\text { Blood \& blood } \\
\text { products }\end{array}$ \\
\hline S. No. & $\begin{array}{c}\text { Health } \\
\text { workers }\end{array}$ & $\begin{array}{c}\text { Correct } \\
\text { answers given } \\
\text { by No.(\%) }\end{array}$ & $\begin{array}{c}\text { Correct answers } \\
\text { given by } \\
\text { No. }(\%)\end{array}$ & $\begin{array}{c}\text { Correct } \\
\text { answers given } \\
\text { by No. }(\%)\end{array}$ & $\begin{array}{c}\text { Correct } \\
\text { answers given } \\
\text { by No. }(\%)\end{array}$ & $\begin{array}{c}\text { Correct } \\
\text { answers given } \\
\text { by No. }(\%)\end{array}$ & $\begin{array}{c}\text { Correct answers } \\
\text { given by } \\
\text { No. }(\%)\end{array}$ \\
\hline 1 & Doctors & $47(94.00)$ & $50(100)$ & $49(98.00)$ & $48(96.00)$ & $24(48.00)$ & $40(80,00)$ \\
\hline 3 & Technicians & $27(54.00)$ & $42(84.00)$ & $48(96.00)$ & $45(90.00)$ & $12(24.00)$ & $42(84.00)$ \\
\hline 4 & Nurses & $38(76.00)$ & $45(90.00)$ & $46(92.00)$ & $44(88.00)$ & $24(48.00)$ & $40(80.00)$ \\
\hline 5 & Class iv & $33(66.00)$ & $39(78.00)$ & $41(82.00)$ & $45(90.00)$ & $17(34.00)$ & $42(84.00)$ \\
\hline Total & & $145(72.50)$ & $176(88.00)$ & $184(92.00)$ & $182(91.00)$ & $77(38.50)$ & $164(82.00)$ \\
\hline P value & & 0.00081 & 0.5853 & 0.0159 & 0.5323 & 0.0338 & 0.9095 \\
\hline
\end{tabular}

$72.5 \%$ of the participants were aware of the transmission of HIV from infected person to others. Majority of doctors (94\%) followed by $76 \%$ of nurses, $66 \%$ of class IV and $54 \%$ of technicians were aware of the infectivity potential of PLHIV's. The difference between the awareness levels among the various categories of HCW's appeared to be very high and it was

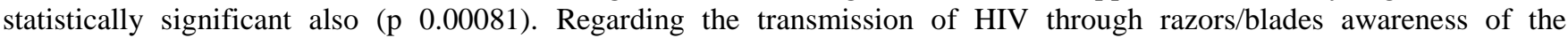
functionaries was slightly better in order of 100\%, 90\%, 645 and 78\% respectively among doctors, nurses, technicians and class IV employees. Potential of transmission through body secretions was better known to them in order of $98 \%, 96 \%, 92 \%$ and $82 \%$ among doctors, technicians, nurses and class IV workers respectively. Awareness of routes of transmission was found to be more than $90 \%$ among all the categories of HCW's. Awareness about the risk of transmission of HIV from mother to child was found to be very low (less than 50\%) among all categories and the difference was found to be statistically significant (0.0338). However, the level of awareness of all types of HCW's about transmission risk through blood and blood products was better (more than $80 \%$ ).

Table 3: distribution of hcw's based on awareness about prevention against HIV infection

\begin{tabular}{|l|l|c|c|c|c|c|c|}
\hline & $\begin{array}{c}\text { Need of } \\
\text { universal } \\
\text { precautions } \\
\text { by HCW's }\end{array}$ & $\begin{array}{c}\text { Need of gloves } \\
\text { for HCW's }\end{array}$ & $\begin{array}{c}\text { Effective } \\
\text { Concentration } \\
\text { of Sodium } \\
\text { hypochlorite } \\
\text { against HIV }\end{array}$ & $\begin{array}{c}\text { Disposal of } \\
\text { used } \\
\text { disposable } \\
\text { syringe }\end{array}$ & $\begin{array}{c}\text { Disposal of } \\
\text { yellow } \\
\text { coloured waste } \\
\text { bags }\end{array}$ & $\begin{array}{c}\text { Handling the } \\
\text { blood } \\
\text { spillage on } \\
\text { floor }\end{array}$ \\
\hline
\end{tabular}




\begin{tabular}{|c|c|c|c|c|c|c|c|}
\hline S. No. & $\begin{array}{c}\text { Health } \\
\text { workers }\end{array}$ & $\begin{array}{c}\text { Correct } \\
\text { answers given } \\
\text { by No. }(\%)\end{array}$ & $\begin{array}{c}\text { Correct } \\
\text { answers given } \\
\text { by No. }(\%)\end{array}$ & $\begin{array}{c}\text { Correct } \\
\text { answers given } \\
\text { by No. }(\%)\end{array}$ & $\begin{array}{c}\text { Correct } \\
\text { answers given } \\
\text { by No. }(\%)\end{array}$ & $\begin{array}{c}\text { Correct answers } \\
\text { given by } \\
\text { No. }(\%)\end{array}$ & $\begin{array}{c}\text { Correct } \\
\text { answers given } \\
\text { by No. }(\%)\end{array}$ \\
\hline 1. & Doctors & $42(84)$ & $46(92)$ & $9(18)$ & $14(28)$ & $33(66)$ & $49(98)$ \\
\hline 2. & Technicians & $44(88)$ & $29(58)$ & $22(44)$ & $6(12)$ & $39(78)$ & $45(90)$ \\
\hline 3. & Nurses & $42(84)$ & $31(62)$ & $5(10)$ & $5(10)$ & $26(52)$ & $45(90)$ \\
\hline 4. & Class iv & $37(74)$ & $36(72)$ & $10(20)$ & $6(12)$ & $33(66)$ & $39(78)$ \\
\hline Total & & $165(82.5)$ & $142(71)$ & $46(23)$ & $31(15.5)$ & $131(65.5)$ & $178(89)$ \\
\hline$P$ value & & 0.2950 & 0.0007 & 0.0004 & 0.0448 & 0.0575 & 0.0206 \\
\hline
\end{tabular}

Regarding the prevention of transmission of HIV in patient care, awareness about the need of universal precautions was found to be in order of $88 \%, 84 \%, 84 \%$ and $74 \%$ among technicians, doctors, nurses and class IV workers and it needs to be reinforced for their safety. Awareness about the need of gloves for HCW's was even lower among technicians, nurses and class IV workers and this difference was statistically significant (P 0.0007). A very low level of awareness $(<50 \%)$ was found among all the types of HCW's about the effective concentration of Sodium hypochlorite against HIV ( over all 23\%) and disposal of syringes (over all 15.5\%) (p value $<0.05$ in both cases) and needs serious steps to be taken in this regard. Regarding the disposal of yellow colored waste bags the awareness was found among less than $80 \%$ of all types of HCW's. However, the awareness about the proper handling of blood spillage on floors was found among a much higher proportion of HCW's $(89 \%)$.

Table 4: Distribution of respondents based on awareness about management of exposure to HIV

\begin{tabular}{|c|c|c|c|c|c|}
\hline & $\begin{array}{c}\text { Maximum Time limit } \\
\text { for starting PEP }\end{array}$ & Duration of PEP & $\begin{array}{c}\text { Diagnostic tests for } \\
\text { HIV }\end{array}$ & Benefits of ART \\
\hline S. No. & $\begin{array}{c}\text { Health } \\
\text { workers }\end{array}$ & $\begin{array}{c}\text { Correct answers given } \\
\text { by No.(\%) }\end{array}$ & $\begin{array}{c}\text { Correct answers } \\
\text { given by No. }(\%)\end{array}$ & $\begin{array}{c}\text { Correct answers } \\
\text { given by No.(\%) }\end{array}$ & $\begin{array}{c}\text { Correct answers } \\
\text { given by No. }(\%)\end{array}$ \\
\hline 1. & Doctors & $42(84.00)$ & $4(8.00)$ & $46(92)$ & $5(10)$ \\
\hline 2. & Technicians & $41(82.00)$ & $4(8.00)$ & $29(58)$ & $11(22)$ \\
\hline 3. & Nurses & $35(70.00)$ & $0(0.00)$ & $27(54)$ & $10(20)$ \\
\hline 4. & Class iv & $30(60.00)$ & $5(10.00)$ & $21(42)$ & $7(14)$ \\
\hline Total & & $14874.00)$ & $13(6.50)$ & $123(61.5)$ & $33(16.5)$ \\
\hline No. & & 0.0206 & 0.1828 & 0.000002 & 0.3472 \\
\hline
\end{tabular}

Regarding the management of cases of exposure to HIV, the awareness about maximum time limit to start PEP was found in order of $84 \%, 82 \%, 70 \%$ and $60 \%$ among doctors, technicians, nurses and class IV workers respectively. (overall 74\%). Knowledge about duration of PEP was drastically low $(<10 \%)$ in all categories of HCW's. Availability of diagnostic tests for HIV infection was known mainly to doctors (92\%) and less than $60 \%$ of other workers. Sadly, the awareness about the benefits of PEP was very poor among all categories of HCW's (overall 16.5).

\section{Discussion}

HIV infection is not only a significant health problem but also one of the most important social issues of the twentyfirst century. ${ }^{7}$ While the basic information about the disease like causative agent, modes of transmission, etc. were known to most of the participants, deficiencies in their prevention and treatment in many critical areas of the disease were noticed. These deficiencies in knowledge influence their behavior thus, exposing them to the risk of transmission.

In the present study, it was observed that among the hospital staff $72.5 \%$ of the participants were aware of the transmission of HIV from infected person to others. Awareness and opinion about HIV/AIDS in the current study was fairly good which is similar to study findings by Dutta et al in Kolkata ${ }^{8}$ and Kumar et al in Delhi among the nursing staff. Though most of them had knowledge of the symptoms and presentation of the disease, they had less knowledge about disinfection, universal precautions, and prophylaxis against exposure to needle stick injury. This is of the utmost importance in health care centers to prevent occupational exposure and iatrogenic transmission.

Awareness about the risk of transmission of HIV from mother to child was found to be very low (less than 50\%) among all categories which was in contrast to the study conducted by lucksom on antenatal mothers where $68 \%$ were aware about mother-to-child transmission of HIV during antenatal period and $2.66 \%$ knew about transmission of HIV in child through breast milk. ${ }^{9}$ In another study conducted by Aziz among health care workers found that $71 \%$ were aware of vertical transmission of HIV. ${ }^{10}$ The awareness about the benefits of PEP was very poor among all categories of HCW's (overall 16.5)

In the present study, however, knowledge of respondents about high-risk groups and curability $(39.1 \%)$ of HIV/AIDS was not satisfactory. Similarly, results were seen in a study by Singh et al., where $11.6 \%$ women told that cure was available for the disease. ${ }^{11}$ 
Finally, it was observed that the knowledge of the respondents was quite satisfactory for most of the variables like modes of transmission of the disease and prevention of disease. However, knowledge of respondents about the benefits of PEP and ART was not satisfactory. This knowledge should be strengthened through various modes like conducting CME, poster displays etc.

\section{Conclusion}

HIV infection and AIDS is a reality in this country and is going to get evermore common. Sensitizing the hospital staff to the various aspects of disease through an active health education programme is crucial if we are to succeed in the endeavor to successfully control the disease.

\section{Source of Funding}

None.

\section{Conflict of Interest}

None.

\section{References}

1. Jaiswal S, Magar BS, Thakali K, Pradhan A, Gurubacharya DL. HIV/AIDS and STI related knowledge, attitude and practice among high school students in Kathmandu valley. Kathmandu Univ Med J(KUMJ). 2005;3(1):69-75.

2. NACO 'HIV sentinel surveillance and HIV estimation in India 2007: A technical brief’ 2007

3. Joint United Nations Programme on HIV/AIDS (UNAIDS) WHOW, AIDS Epidemic Update: December 2006. UNAIDS. 2006
4. Joint United Nations Program on HIV/AIDS (UNAIDS) WHOW, AIDS Epidemic Update: December 2007. UNAIDS. 2007

5. Dandona L, Dandona R. Drop of HIV estimate for India to less than half. Lancet 2007;370:1811-3.

6. Kumar, R., Mohan, N., Seenu, V., Kumar, A., \& Nandi, M. Knowledge, attitude and practices towards HIV among nurses in a tertiary care, teaching hospital: Two decades after discovery. J Commun Dis 2002;34;(4)245-56.

7. Kumar A, Lal P, Ingle G.K, \& Gulati N. AIDS-related apprehensions among nursing students of Delhi. J Comm Dis., 1999;31(4):217-21

8. Datta C., \& Bandopadhyay D. Knowledge and attitude in relation to HIV/ AIDS among in-service nurses of Calcutta. J. Indian Med. Association, 1997;95;3"7577.

9. Lucksom PG, Upadhya R, Kharka L, Dubey S, Choudhary N, Yadav R et al. KAP Study on HIV/AIDS Among Antenatal Women Attending Central Referral Hospital of North East India. J Obstet Gynaecol India 2016;66(1):55-9.

10. Aziz S, Memon A, Tily HI, Rasheed K, Jehangir K, Quraishy MS. Prevalence of HIV, hepatitis B and C amongst health workers of Civil Hospital Karachi. J Pak Med Assoc 2002;52(3):92-4.

11. Singh A, Khan S, Chaudhary V, Narula K, Zaidi ZH. Knowledge and awareness about HIV/AIDS among women of reproductive age in a District of Northern India. Natl $J$ Community Med 2012;3:417-22.

How to cite this article: Rakesh $\mathrm{D}$, Mahajan $\mathrm{R}$, Ghai S. Awareness of HIV among health care workers in a tertiary care hospital of Jammu. Indian J Forensic Community Med 2019;6(3):130-3. 